\title{
Investigating Tertiary Level EFL Learners' Willingness to Communicate in English
}

\author{
Tutku Başöz ${ }^{1} \&$ İsmail Hakkı Erten ${ }^{2}$ \\ ${ }^{1}$ Department of English Language Teaching, Balıkesir University, Balıkesir, Turkey \\ ${ }^{2}$ Department of English Language Teaching, Hacettepe University, Ankara, Turkey \\ Correspondence: Tutku Başöz, Department of English Language Teaching, Balıkesir University, Balıkesir, \\ Turkey. E-mail: tutkubasoz@hotmail.com
}

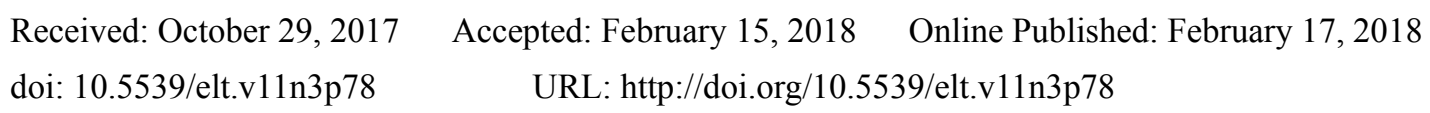

\begin{abstract}
The present study aimed to investigate Turkish EFL learners' perceived levels of willingness to communicate (WTC) in English inside and outside the classroom. The study also aimed to explore whether there is a statistically significant difference between their in-class WTC in English and out-of-class WTC in English. The study, which employed a quantitative research design, was conducted with the participation of 701 EFL learners enrolled in the departments of Tourism Guidance and Tourism Management at Ballkesir University Faculty of Tourism located in Balıkesir, Turkey. The data collection instrument included a scale which measures the participants' perceived levels of WTC in English. The data were analyzed descriptively through IBM SPSS 21. The findings of the study indicated that EFL learners have a moderate level of WTC in English. The findings also showed that there was a statistically significant difference between the participants' perceived levels of their in-class WTC in English and their out-of-class WTC in English. It was found that they are more willing to communicate in English outside the classroom than they are inside the classroom. In the light of the findings, some practical recommendations were also noted.
\end{abstract}

Keywords: WTC in English, tertiary level EFL learners, individual differences, in-class WTC in English, out-of-class WTC in English

\section{Introduction}

Recent second language (L2) pedagogy has attached great importance to the use of L2 both inside and outside the classroom with the intention of developing language learners' communicative competence. There has been an intensive focus on communicative approaches to language teaching, which place greater emphasis on the engagement of language learners in communication (Savignon, 2005). This emphasis upon the active use of target language in L2 classrooms posits the idea that "learners have to talk in order to learn" (Skehan, 1989, p. 48). Theories of language acquisition such as Long's (1985) Interaction Hypothesis and Swain's (1985) Comprehensible Output Hypothesis have also highlighted the significance of interaction and comprehensible output in second language learning and made significant contributions to the recent emphasis attached to Communicative Language Teaching.

As the use of L2 has been widely acknowledged as an indicator of and an important prerequisite to successful L2 learning (Ellis, 2008; Seliger, 1977; Swain, 1985), willingness to communicate in a second language (L2 WTC), as a recent addition to individual difference (ID) variables, is regarded to be a construct of obvious relevance to L2 learning and as "the most immediate determinant of L2 use" (Clément, Baker, \& MacIntyre, 2003, p. 191). A greater L2 WTC will result in better L2 development and more effective communication in various communication settings (MacIntyre, Dörnyei, Clément, \& Noels, 1998). To put it differently, as "a means and an end at the same time" (Dörnyei, 2005, p. 210), L2 WTC takes the role of both the individual difference variable facilitating the second language learning process and final objective of L2 instruction (MacIntyre et al., 1998). It is a complex ID variable that integrates a number of learner variables which have been widely accepted to exert influence on second language acquisition (Dörnyei, 2005).

The aforementioned advantages of L2 WTC have provided the main impetus for researchers to examine learners' L2 WTC (Ellis, 2008). Over the last two decades, L2 WTC has received enormous interest in the realm of L2 
acquisition and an increasing number of studies have been carried out so as to determine learners' L2 WTC level and the factors affecting their L2 WTC. However, the majority of these studies investigated learners' WTC and its relation to other variables in the English as a Second Language (ESL) context. Thus, it seems necessary to gain further insight into this key individual difference variable in the English as a Foreign Language (EFL) context, in which learners usually do not have any opportunity to use English outside the classroom. Furthermore, although many studies have been conducted on WTC in various L2 learning contexts, WTC research in the Turkish EFL context is still in its infancy. Only a limited number of studies (Asmal1, 2016; Asmal1, Bilki \& Duban, 2015; Bursalı \& Öz, 2017; Çetinkaya, 2005; Kanat-Mutluoğlu, 2016; Öz, 2014, 2016; Öz, Demirezen, \& Pourfeiz, 2015; Şener, 2014) have been conducted in Turkey. Regarding this research gap, the present study aimed to probe Turkish EFL learners' perceived levels of WTC in English inside and outside the classroom. The study also aimed to explore whether there is a statistically significant difference between Turkish EFL learners' WTC in English inside the classroom and their WTC in English outside the classroom.

\section{Literature Review}

\subsection{Willingness to Communicate in a Second Language (L2 WTC)}

Individual difference variables in language learning have been the focus of research for more than 50 years (Gardner, 2009). One of the individual difference variables that have been the center of attraction in L2 research is WTC, which originated in the field of first language (L1) communication (Ellis, 2008). The concept of WTC, which was developed by McCroskey and Baer (1985), is described as the intention to engage in communication when given the opportunity. It is also defined as "an individual's personality-based predisposition to approaching or avoiding the initiation of communication when free to do so" (McCroskey, 1997, p. 77). Thus, WTC is understood as a construct that represents a psychological readiness to initiate communication, specifically talk.

The origins of the WTC construct go back to the L1 communication research (Burgoon, 1976; McCroskey, 1977; McCroskey \& Richmond, 1982; Mortensen, Arntson, \& Lustig, 1977; Phillips, 1968) and can be seen in some related constructs such as reticence, communication apprehension, unwillingness to communicate, predispositions to verbal behaviour, and shyness (MacIntyre, 2007). McCroskey and Baer (1985) introduced WTC as a more specific construct with its focus on speaking. It was conceptualized as a personality-based, trait-like construct, which is constant across diverse communication situations and receivers (McCroskey \& Richmond, 1990). Moreover, it was regarded as a personality orientation, which explains why some people appear to be more willing to communicate than others under identical situations (McCroskey \& Richmond, 1990). Such variability in communicative behavior among people paved the way for the introduction of a new concept called WTC. WTC, as an overpowering communication personality construct, is considered to influence every aspect of one's life and contribute enormously to one's social, educational, and organizational success (Richmond \& Roach, 1992).

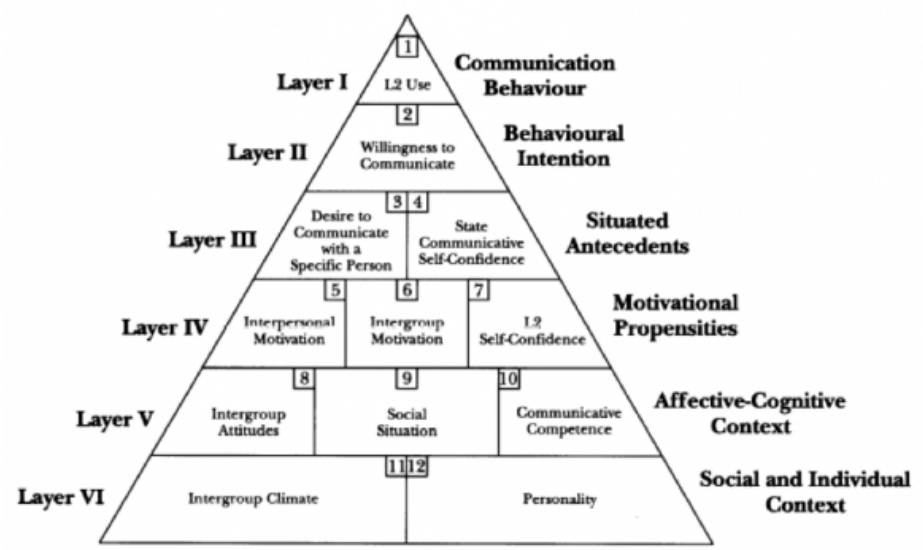

Figure 1. The heuristic model of L2 WTC (MacIntyre et al., 1998)

Originally introduced by McCroskey and Baer (1985) with regard to L1 communication, the WTC construct was later applied to second language communication situations and redefined as "a readiness to enter into a discourse at a particular time with a specific person or persons, using an L2" by MacIntyre and his associates (1998, p. 547). It refers to a multifaceted construct that integrates psychological, linguistic, educational and communicative dimensions of language (MacIntyre, Burns, \& Jessome, 2011). The often-cited heuristic model 
presented in Figure 1 (MacIntyre et al., 1998) is comprised of many variables in a six-layered pyramid and provides a comprehensive account of linguistic, communicative and social psychological factors that potentially influence L2 WTC and thus the real use of L2 (Jung, 2011).

As illustrated by the figure above, at the base of the pyramid, there are relatively fixed factors, such as personality and intergroup climate. At the highest point of the pyramid, there is real L2 use in a particular situation. In between these two ends there exists an array of situational and contextual factors that merge with learner characteristics such as communicative competence and/or L2 self-confidence. From the highest point to the base of the pyramid, the layers indicate a transition from the most instant, situation-specific circumstances to the more constant, lasting effects on L2 communication process. In this model, a large number of contextual and individual factors harmonize at any one moment to cause a learner using or not using the L2 (Williams, Mercer, \& Ryan, 2015). Along with the introduction of this seminal model, WTC was reconceptualized as a situational variable subject to change across a variety of contexts.

To put it in a nutshell, as an intriguing construct, L2 WTC provides an integration of psychological, linguistic, educational and communicative approaches to second language research that has been commonly carried out independently (MacIntyre, 2007). An interesting fact claimed by MacIntyre (2007) is that L2 WTC takes the role of both the individual difference variable facilitating second language acquisition process, particularly in an educational system that gives priority to communication, and the non-linguistic outcome of the L2 learning. It is also considered as the most direct indicator of L2 use (Clément et al., 2003). It is in this connection that WTC has been considered to be a key concept in L2 learning and teaching and some research studies have been carried out to probe language learners' L2 WTC over the last two decades. In a study (Ghonsooly, Hosseini Fatemi, \& Khajavy, 2013) conducted in the Iranian EFL context, for instance, it was found that Iranian EFL learners are moderately willing to communicate in English in the classroom. The findings of the study of Pavičić Takač and Požega (2011), on the other hand, revealed that Chinese EFL learners' L2 WTC is at a low level. In a recent study (Wang \& Liu, 2017), it was also found that EFL learners have a low level of WTC in English. In Bukhari and Cheng's study (2017), which was conducted in the ESL context, the learners' L2 WTC was revealed to be at a high level. As for the Turkish EFL context, the research studies (Bursalı \& Öz, 2017; Çetinkaya, 2005; Öz, 2014, 2016; Öz et al., 2015; Şener, 2014) showed that Turkish EFL learners have a moderate level of WTC in English. Similarly, Mari, Pathan and Shahriar (2011) reported that Pakistani university students' WTC in English is neither high nor low.

\section{The Study}

\subsection{Research Questions}

The purpose of the present study was to investigate Turkish EFL learners' perceived levels of WTC in English inside and outside the classroom. The study also attempted to explore whether there is a statistically significant difference between Turkish EFL learners' WTC in English inside the classroom and their WTC in English outside the classroom. In this context, the study aimed to answer the following research questions:

1). What are the Turkish EFL learners' perceived levels of WTC in English inside and outside the classroom?

2). Is there any statistically significant difference between the Turkish EFL learners' perceived levels of WTC in English inside the classroom and their perceived levels of WTC in English outside the classroom?

\subsection{Setting and Participants}

The study was carried out at Balıkesir University Faculty of Tourism which is located in Balıkesir, Turkey. From the non-probability sampling procedures, convenience sampling method was employed to collect data from the participants as they were selected on the basis of certain practical criteria such as geographical proximity and easy accessibility. 701 EFL learners enrolled in the departments of Tourism Guidance and Tourism Management in the 2016-2017 academic year took part in the study. The mean age of the participants was 20.90 (SD $=1.88$, minimum $=18$; maximum $=34)$. Of the participants, $284(40.5 \%)$ were female and $417(59.5 \%)$ were male. 274 (39.1\%) of the participants were enrolled in the department of Tourism Guidance whereas $427(60.9 \%)$ of them were studying in the department of Tourism Management. Freshmen $(n=204 ; 29.1 \%)$, sophomores $(n=235$; $33.5 \%)$, juniors $(\mathrm{n}=147 ; 21 \%)$, and seniors $(\mathrm{n}=115 ; 16.4 \%)$ were included into the study.

\subsection{Instruments}

The participants' perceived levels of WTC in English were determined using the adapted version of the L2 WTC Scale (MacIntyre, Baker, Clément, \& Conrod, 2001). The scale was selected to find out EFL learners' perceived levels of WTC in English as it was designed specifically to measure L2 WTC while other measures of WTC such as McCroskey`s (1992) scale estimate the degree of general WTC. It is a 54-item scale, which is composed of 
two sections: WTC in English in the classroom and WTC in English outside the classroom. The participants were expected to specify on a 5-point Likert scale how willing they are to communicate in English. The first part of the scale consists of a total of 27 items referring to the participants' eagerness to involve in communication activities in class. In the second part of the scale, on the other hand, there were 27 items, all of which refer to the participants' enthusiasm for participating in out-of-class communication.

In order to prevent any influence because of the low proficiency levels of the participants, such as misunderstanding the statements, or not understanding at all, the scale was translated into Turkish through translation and back translation methods (Brislin, 1980). The results of the analysis of the raters' responses as to how synonymous the Turkish and English versions on a scale of 10 indicated a mean score of 9.7/10, signifying a high level of semantic correspondence between the two versions. The synonymy between items in the original English version and the back-translated English version was found as 9.1/10, which also reveals a high level of semantic correspondence between these versions. In the current study, the reliability coefficients of each section of the Turkish version of the scale were found as the following: WTC in English inside the classroom: (27 items, $\alpha=.93$ ), WTC in English outside the classroom: (27 items, $\alpha=.94)$.

\subsection{Data Collection Procedures}

Necessary permissions for data collection were granted from the Dean of Balıkesir University Faculty of Tourism. The data were collected during the students' regular class time. Only the learners who were willing to take part in the study were given the L2 WTC scale after they signed the official consent form. The data collection lasted about 20 minutes for each class. The researcher was available in classes during the process so that she could have an opportunity to clarify the points that might be confusing to the respondents.

\subsection{Data Analysis}

A test of normality was performed to find out whether the data were normally distributed or not. Kolmogorov-Smirnov and Shapiro-Wilk tests revealed numerical results of non-normal distribution. However, as Pallant (2010) states, this is a commonly observed situation in large samples and the real shape of the distribution can be viewed in histograms or normal probability plots. As the present study had a quite large sample, there was a need to look at these normal probability plots so as to make sure that the data were normally distributed. According to the normal probability plots, the data displayed a normal distribution with reasonably straight lines. Moreover, the assumption of normality was confirmed because the values of skewness and kurtosis seemed to fall between -2 and +2 (Kunnan, 1998). Thus, the researcher preferred to use parametric tests rather than non-parametric ones based on the conclusion that the data were normally distributed. The data were analyzed descriptively by means of IBM SPSS 21 . Descriptive statistics were performed, and mean values and standard deviations of the variables were calculated. A paired samples t-test was also carried out to discover whether there was a significant difference between the participants' perceived levels of their in-class WTC in English and out-of-class WTC in English.

\section{Results and Discussion}

\subsection{What Are the Turkish EFL Learners' Perceived Levels of WTC in English Inside and Outside the Classroom?}

To explore the participants' levels of WTC in English inside and outside the classroom, descriptive statistics were employed. Following Kalra (2017), Lian and Budin (2014), and Wimolmas (2013), the mean scores were divided into three categories simply by using the formula 'maximum value of mean score (5.00) - minimum value of mean score (1.00) / number of categories (3). Thus, the mean scores which were between 1.00-2.33 were categorized as low WTC, those which fell between 2.34-3.67 were accepted as moderate WTC and those between 3.68-5.00 were assumed to be high WTC. The following table shows the mean scores and standard deviations of each item in the L2 WTC scale.

Table 1. Descriptive statistics: WTC in English inside and outside the classroom including scale items

\begin{tabular}{lllll}
\hline Inside & & Willingness to Communicate in English & Outside \\
\hline Mean* & SD & Item Description & Mean* & SD \\
\hline 2.76 & 1.24 & Speak in a group about your summer vacation & 3.00 & 1.36 \\
2.49 & 1.22 & Speak to your teacher about your homework assignment & 2.44 & 1.31 \\
3.77 & 1.14 & Have a conversation with a stranger if he/she talks to you first & 3.87 & 1.17
\end{tabular}




\begin{tabular}{lllll}
3.27 & 1.27 & $\begin{array}{l}\text { Ask for instructions/clarification when you are confused about a } \\
\text { task you must complete }\end{array}$ & 3.17 & 1.34 \\
2.96 & 1.27 & Talk to a friend while waiting in line & 3.14 & 1.38 \\
2.28 & 1.39 & Be an actor in a play & 2.38 & 1.45 \\
2.82 & 1.40 & Describe the rules of your favorite game & 2.82 & 1.42 \\
3.22 & 1.39 & Play a game in English, for example Monopoly & 3.26 & 1.43 \\
2.73 & 1.33 & Read an English novel & 2.89 & 1.43 \\
2.65 & 1.33 & Read an English article in a paper & 2.68 & 1.43 \\
3.21 & 1.39 & Read letters from a pen pal written in native English & 3.24 & 1.41 \\
3.32 & 1.35 & Read personal letters or notes written to you in which the writer & 3.26 & 1.37 \\
& & has deliberately used simple words and constructions & & \\
2.71 & 1.32 & Read an advertisement in the paper to find good merchandise, e.g. & 2.80 & 1.38 \\
& & a book, you can buy & 3.35 & 1.43 \\
3.23 & 1.38 & Read reviews in English for popular movies & 2.52 & 1.41 \\
2.41 & 1.36 & Write an invitation to invite your schoolmates to a weekend party \\
2.60 & 1.33 & Write down the instructions for your favorite hobby & 2.50 & 1.35 \\
2.37 & 1.31 & Write a report on your favorite animal and its habits & 2.41 & 1.39 \\
2.23 & 1.29 & Write a story & 2.26 & 1.32 \\
2.64 & 1.37 & Write a letter to a friend & 2.77 & 1.45 \\
1.94 & 1.23 & Write a newspaper article & 2.00 & 1.29 \\
2.96 & 1.40 & Write the answers to a "fun" quiz from a magazine & 3.08 & 1.42 \\
2.49 & 1.38 & Write down a list of things you must do tomorrow & 2.57 & 1.41 \\
2.84 & 1.29 & Listen to instructions in English and complete a task & 2.98 & 1.35 \\
2.74 & 1.51 & Bake a cake if instructions were in English & 2.90 & 1.59 \\
3.08 & 1.33 & Fill out an application form in English & 3.16 & 1.34 \\
3.37 & 1.32 & Take directions from an English speaker & 3.52 & 1.33 \\
4.11 & 1.13 & Understand an English movie & $\mathbf{2 . 9 3}$ & $\mathbf{1 . 3 7}$ \\
\hline $\mathbf{2 . 8 6}$ & $\mathbf{1 . 3 2}$ & Total WTC Score & & 1.12 \\
\hline & & & & \\
& & & &
\end{tabular}

Note. *1.00- 2.33: Low; 2.34-3.67: Moderate; 3.68-5.00: High.

The participants' overall WTC in English inside the classroom was revealed to be moderate $(\mathrm{M}=2.86, \mathrm{SD}=$ 1.32). The mean value for WTC in English outside the classroom was $2.93(\mathrm{SD}=1.37)$, which means that the participants had a moderate level of WTC in English outside the classroom as well. As can be seen in the table, the participants were highly willing to understand an English movie $(\mathrm{M}=4.11, \mathrm{SD}=1.13)$, and have a conversation with a stranger if he/she talks to them first $(\mathrm{M}=3.77, \mathrm{SD}=1.14)$ inside the classroom. Likewise, they were highly willing to understand an English movie $(\mathrm{M}=4.17, \mathrm{SD}=1.12)$ and have a conversation with a stranger $(\mathrm{M}=3.87, \mathrm{SD}=1.17)$ outside the classroom. The results also indicated that the participants had a low level of willingness to write a newspaper article $(\mathrm{M}=1.94, \mathrm{SD}=1.23)$, write a story $(\mathrm{M}=2.23, \mathrm{SD}=1.29)$, and be an actor in a play $(\mathrm{M}=2.28, \mathrm{SD}=1.39)$ inside the classroom. As for the outside of the classroom, the findings were similar with writing a newspaper article $(\mathrm{M}=2.00, \mathrm{SD}=1.29)$ and writing a story $(\mathrm{M}=2.26, \mathrm{SD}$ $=1.32$ ) having the lowest mean scores. 
Table 2. Descriptive statistics: EFL learners' perceived levels of their WTC in English inside and outside the classroom

\begin{tabular}{llllll}
\hline & Rank & F & \% & Mean* & SD \\
\hline \multirow{2}{*}{$\begin{array}{l}\text { L2 WTC inside the } \\
\text { classroom }\end{array}$} & High & 230 & 32.7 & 4.01 & .71 \\
& Moderate & 240 & 34.2 & 2.86 & .78 \\
\multirow{2}{*}{$\begin{array}{l}\text { L2 WTC outside the } \\
\text { classroom }\end{array}$} & Low & 231 & 33.1 & 1.76 & .44 \\
& High & 228 & 32.4 & 4.03 & .69 \\
& Moderate & 239 & 34.1 & 2.93 & .86 \\
\hline
\end{tabular}

Note. *1.00- 2.33: Low; 2.34-3.67: Moderate; 3.68-5.00: High.

Frequencies and percentages were also calculated and the participants were categorized into three groups according to their WTC level: low, moderate, and high. As given in Table 2, 32.7\% of the participants had high, $34.2 \%$ had moderate, and $33.1 \%$ had low L2 WTC inside the classroom. According to the descriptive statistics for willingness to communicate outside the classroom, $32.4 \%$ of the participants had high, $34.1 \%$ had moderate, and $33.5 \%$ had low WTC in English. In brief, the findings revealed that tertiary level learners had a moderate level of WTC in English both inside and outside the classroom.

4.2 Is There Any Statistically Significant Difference Between the Turkish EFL Learners' Perceived Levels of WTC in English Inside the Classroom and Their Perceived Levels of WTC in English Outside the Classroom?

The descriptive statistics presented in Table 2 demonstrated that the participants had a moderate level of both in-class and out-of-class L2 WTC. However, a paired samples t-test was carried out to explore whether there was a statistically significant difference between the participants' perceived levels of WTC in English inside the classroom and their perceived levels of out-of-class WTC in English. The statistical findings are presented in the table below:

Table 3. A comparison of the EFL learners' perceived levels of their WTC in English inside and outside the classroom

\begin{tabular}{llllllll}
\hline & N & Mean & SD & MD & t & df & Sig. \\
\hline L2 WTC inside the classroom & 701 & 2.86 & .78 & \multirow{2}{*}{-.071} & -.4 .594 & 701 & .000 \\
L2 WTC outside the classroom & 701 & 2.93 & .86 & & & & \\
\hline
\end{tabular}

The findings of the paired samples t-test illustrated in the table above showed that there was a statistically significant difference between the participants' perceived levels of their in-class L2 WTC $(\mathrm{M}=2.86, \mathrm{SD}=.78)$ and their perceived levels of their out-of-class L2 WTC $(\mathrm{M}=2.93, \mathrm{SD}=.86), \mathrm{t}(701)=-4.594, \mathrm{p}<.05$ (two-tailed). The eta squared statistic (.03) demonstrated a small effect size (Cohen, 1988, pp. 284-287). Therefore, the participants appeared to be more eager to speak English outside the classroom than they did inside the classroom.

In the current study, the participants' WTC in English was discovered to be moderate, which is considerably in line with the previous research studies (Ghonsooly et al., 2013; Bursalı \& Öz, 2017; Çetinkaya, 2005; Mari et al., 2011; Nagy, 2007; Öz, 2014, 2016; Öz et al., 2015; Şener, 2014) in the literature. However, this finding is not consistent with the findings of Pavičić Takač and Požega (2011) and Wang and Liu (2017) who found that the learners had a low level of L2 WTC. In Bukhari and Cheng's study (2017), which was conducted in the ESL context, on the contrary, the learners' L2 WTC was revealed to be at a high level. This is perhaps because of the significant effect of L2 learning context on an individual's WTC as pointed out by Cameron (2013). It is noteworthy that the L2 WTC level of the EFL learners was found to be moderate in all studies (Bursalı \& Öz, 2017; Çetinkaya, 2005; Öz, 2014, 2016; Öz et al., 2015; Şener, 2014) carried out in the Turkish EFL context. Moreover, ESL learners' high WTC in English reported in Bukhari and Cheng's study (2017) can be attributed to ample opportunities of them to use English in real-life communication. Conversely, EFL learners generally do not have any chance of using the target language outside the classroom (Oxford \& Shearin, 1994), which may, in 
turn, result in relatively lower levels of L2 WTC.

It was also revealed in this study that there was a statistically significant difference between the participants' perceived levels of their in-class L2 WTC and their out-of-class L2 WTC. The tertiary level Turkish EFL learners seemed to be more willing to speak English outside the classroom than they did inside the classroom. Previous research (Ahola-Houtsonen, 2013; Kostiainen, 2015; Nagy, 2007; Peng, 2015) supports the findings regarding learners' higher out-of-class WTC than in-class WTC in English. There may be some possible explanations for this finding. Conversations in a classroom environment typically lack a natural flow since learners must talk and take part in the activities to get a good grade; thus, they think that they must talk correctly, and they constantly feel assessed (Nagy, 2007). Learners are more likely to maintain their willingness to communicate when they are outside the class and are not being compelled to speak English as they were in the classroom (Peng, 2015). To put it differently, they are more willing to communicate in English outside the classroom as there is nobody who evaluates what they say (Kostiainen, 2015). In brief, this study, consistent with previous research (Ahola-Houtsonen, 2013; Kostiainen, 2015; Nagy, 2007; Peng, 2015), suggested that out-of-class L2 WTC was higher than in-class WTC among EFL learners. This finding implies that L2 WTC is not likely to be one-dimensional phenomenon and its intricacy should be taken into consideration in any attempt to measure it (Peng, 2015).

\section{Conclusion}

This study attempted to probe EFL learners' perceived levels of WTC in English as well as to find out whether the levels of their in-class L2 WTC and out-of-class L2 WTC differ. Based on the findings, it was concluded that that learners in an EFL context have a moderate level of WTC in English. It was also revealed that they are more willing to communicate in English outside the classroom than they are inside the classroom.

The findings of this research study provide some pedagogical implications that would be helpful for language teachers, instructors, and teacher trainers. As EFL learners generally do not have any opportunity to use English outside the classroom and do not have immediate access to foreigners to have real-life conversations, language teachers and instructors should create environments for EFL learners to communicate in English. They might consider starting an English conversation club for all levels of learners in which they can interact freely with their friends without worrying about their grades. Moreover, language teachers and instructors need to provide various types of interactive tasks for pair, small or large group, or whole class work so that learners can engage in various modes of communication contexts. The emphasis should be placed on speaking rather than grammar adopting a communicative approach in language classrooms. EFL teachers and instructors should bear in their mind that the frequency and amount of target language communication significantly contribute to learners' readiness to communicate in English (Yashima, Zenuk-Nishide, \& Shimizu, 2004). Lastly, as communication is regarded to be the ultimate aim of L2 instruction (MacIntyre \& Charos, 1996), foreign language teacher education programs, in which the first seeds of change are sown, should lay a special emphasis upon developing communication skills of prospective EFL teachers (Öz et al., 2015).

The study was not without limitations. The first limitation was that the L2 WTC scale employed in this study was originally developed for the ESL context. Thus, some responses to the scale items were mostly based on the learners' beliefs in what way they would respond under imaginary circumstances. Another limitation was that the study was carried out with the participation of only tertiary level EFL learners. Therefore, any further generalization from this study should be done with caution, considering the setting and the participants of the study. The focus of the present study was limited to the speaking mode of L2 WTC. Nevertheless, as MacIntyre and his associates (1998) claim, L2 WTC not only includes the speaking mode but also other modes of communication. Therefore, further research could center on L2 WTC not only in the oral mode but also in other modes such as reading, writing and comprehension to gain a more comprehensive picture of L2 WTC. Since L2 WTC is a context-specific construct, this study might be replicated in different EFL contexts among learners with diverse cultural, educational, and socioeconomic backgrounds. Lastly, further research on L2 WTC might be conducted using a mixed-methods research design in order to gain a better understanding of the situated and dynamic nature of L2 WTC and more beneficial insights into its role in foreign language education.

Note. This research is based on a PhD thesis (Başöz, 2018) submitted to the Graduate School of Educational Sciences of Hacettepe University, Ankara, Turkey. 


\section{References}

Ahola-Houtsonen, T. (2013). Learning and teaching English speaking skills at upper secondary school: the students' and the teachers' views. Unpublished master's thesis. University of Jyväskylä, Jyväskylä, Finland.

Asmal1, M. (2016). Willingness to Communicate of Foreign Language Learners in Turkish Context. Procedia-Social and Behavioral Sciences, 232, 188-195. https://doi.org/10.1016/j.sbspro.2016.10.044

Asmal, M., Bilki, U., \& Duban, C. A. (2015). A Comparison of the Turkish and Romanian students' willingness to communicate and its affecting factors in English. Journal of Language and Linguistic Studies, 11(1), 59-74.

Brislin, R. W. (1980). Translation and content analysis of oral and written material. In H. C. Triandis \& J. W. Berry (Eds.), Handbook of cross-cultural psychology, (pp. 389-444). Boston: Allyn \& Bacon.

Bukhari, S. F., \& Cheng, X. (2017). To do or not to do: willingness to communicate in the ESL context: Pakistani students are highly willing to communicate in English in Canada. English Today, 33(1), 36-42. https://doi.org/10.1017/S0266078416000481

Burgoon, J. K. (1976). The unwillingness to communicate scale: Development and validation. Communications Monographs, 43(1), 60-69. https://doi.org/10.1080/03637757609375916

Bursal, N., \& Öz, H. (2017). The relationship between Ideal L2 Self and Willingness to Communicate inside the Classroom. International Journal of Higher Education, 6(4), 229-239. https://doi.org/10.5430/ijhe.v6n4p229

Cameron, D. (2013). Willingness to communicate in English as a second language as a stable trait or context-influenced variable. Australian Review of Applied Linguistics, 36(2), 177-196. https://doi.org/10.1075/aral.36.2.04cam

Clément, R., Baker, S. C., \& MacIntyre, P. D. (2003). Willingness to Communicate in a Second Language: The Effects of Context, Norms, and Vitality. Journal of Language and Social Psychology, 22(2), 190-209. https://doi.org/10.1177/0261927X03022002003

Cohen, J. W. (1988). Statistical power analysis for the behavioral sciences (2nd ed.) Hillsdale, NJ: Lawrence Erlbaum Associates.

Çetinkaya, Y. B. (2005). Turkish college students' willingness to communicate in English as a foreign language. Unpublished doctoral dissertation. The Ohio State University, Colombus.

Dörnyei, Z. (2005). The psychology of the language learner: Individual Differences in Second Language Acquisition. US: Lawrence Erlbaum Associates. https://doi.org/10.1177/0261927X05281424

Ellis, R. (2008). The Study of Second Language Acquisition. Oxford, UK: Oxford University Press.

Gardner, R. C. (2009, May) Gardner and Lambert (1959): Fifty years and counting. Paper presented at the annual meeting of the Canadian Association of Applied Linguistics, Ottawa, Canada.

Ghonsooly, B., Hosseini Fatemi, A., \& Khajavy, G. H. (2013). Examining the relationships between willingness to communicate in English, communication confidence, and classroom environment. International Journal of Research Studies in Educational Technology, 3(1), 63-71. https://doi.org/10.5861/ijrset.2013.392

Jung, M. (2011). Korean EFL university students' willingness to communicate in English. Unpublished doctoral dissertation. Indiana University, USA.

Kalra, R. (2017). The Effectiveness of Using Films in the EFL Classroom: A Case Study Conducted at an International University in Thailand. Arab World English Journal (AWEJ), 8(3), 289-30. https://doi.org/10.24093/awej/vol8no3.19

Kanat-Mutluoğlu, A. (2016). The Influence of Ideal L2 self, Academic Self-Concept and Intercultural Communicative Competence on Willingness to Communicate in a Foreign Language. Eurasian Journal of Applied Linguistics, 2(2), 27-46.

Kostiainen, E. (2015). Classroom context's influence on students' willingness to communicate: a study of upper secondary school students' views. Unpublished master's thesis. University of Jyväskylä, Jyväskylä, Finland.

Kunnan, A. J. (1998). An introduction to structural equation modeling for language assessment research. Language Testing, 15(3), 295-332. https://doi.org/10.1177/026553229801500302

Lian, L. H., \& Budin, M. B. (2014). Investigating the Relationship between English Language Anxiety and the Achievement of School based Oral English Test among Malaysian Form Four Students. International Journal of Learning, Teaching and Educational Research, 2(1), 67-79. 
Long, M. H. (1985). Input and second language acquisition theory. In S. Gass., \& C. Madden, (Eds.), Input in second language acquisition (pp. 377-393). Rowley, Mass: Newbury House.

MacIntyre, P. D. (2007). Willingness to communicate in the second language: Understanding the decision to speak as a volitional process. The Modern Language Journal, 91(4), 564-576. https://doi.org/10.1111/j.1540-4781.2007.00623.x

MacIntyre, P. D., Baker, S. C., Clément, R., \& Conrod, S. (2001). Willingness to communicate, social support, and language-learning orientations of immersion students. Studies in Second Language Acquisition, 23(3), 369-388. https://doi.org/10.1017/S0272263101003035

MacIntyre, P. D., Burns, C., \& Jessome, A. (2011). Ambivalence about communicating in a second language: A qualitative study of French immersion students' willingness to communicate. The Modern Language Journal, 95(1), 81-96. https://doi.org/10.1111/j.1540-4781.2010.01141.x

MacIntyre, P. D., \& Charos, C. (1996). Personality, attitudes, and affect as predictors of second language communication. Journal of Language and Social Psychology, 15(1), 3-26. https://doi.org/10.1177/0261927X960151001

MacIntyre, P. D., Dörnyei, Z., Clément, R., \& Noels, K. A. (1998). Conceptualizing willingness to communicate in an L2: A situational model of L2 confidence and affiliation. The Modern Language Journal, 82(4), 545-562. https://doi.org/10.1111/j.1540-4781.1998.tb05543.x

Mari, M., Pathan, H., \& Shahriar, A. (2011). Willingness to communicate in L2: A perception of Pakistani university students. ELF Annual Research Journal, 13, 65-82.

McCroskey, J. C. (1997). An introduction to rhetorical communication. Needham Heights, MA: Allyn \& Bacon.

McCroskey, J. C. (1977). Oral communication apprehension: A summary of recent theory and research. Human Communication Research, 4(1), 78-96. https://doi.org/10.1111/j.1468-2958.1977.tb00599.x

McCroskey, J. C. (1992). Reliability and validity of the willingness to communicate scale. Communication Quarterly, 40(1), 16-25. https://doi.org/10.1080/01463379209369817

McCroskey, J. C., \& Baer, J. E. (November, 1985). Willingness to communicate: The construct and its measurement. Paper presented at the Annual Convention of the Speech Communication Association, Denver, $\mathrm{CO}$.

McCroskey, J. C., \& Richmond, V. P. (1982). Communication apprehension and shyness: Conceptual and operational distinctions. $\quad$ Communication $\quad$ Studies, $33(3), \quad 458-468$. https://doi.org/10.1080/10510978209388452

McCroskey, J. C., \& Richmond, V. P. (1990). Willingness to communicate: A cognitive view. Journal of Social Behavior and Personality, 5(2), 19.

Mortensen, C. D., Arntson, P. H., \& Lustig, M. (1977). The measurement of verbal predispositions: Scale development and application. Human Communication Research, 3(2), 146-158. https://doi.org/10.1111/j.1468-2958.1977.tb00513.x

Nagy, B. C. (2007). To will or not to will: Exploring advanced EFL learners' willingness to communicate in English. Unpublished doctoral dissertation, University of Pécs, Hungary.

Oxford, R.L., \& Shearin, J. (1994). Language learning motivation: Expanding the theoretical framework. Modern Language Journal, 78, 12-28. https://doi.org/10.1111/j.1540-4781.1994.tb02011.x

Öz, H. (2014). Big Five personality traits and willingness to communicate among foreign language learners in Turkey. Social Behavior and Personality: An International Journal, 42(9), 1473-1482. https://doi.org/10.2224/sbp.2014.42.9.1473

Öz, H. (2016). Role of the ideal L2 self in predicting willingness to communicate of EFL students. In İ. H. Mirici, İ. H. Erten, H. Öz, \& I. Vodopija-Krstanovic (Eds.), Research papers as an Additional Language (pp. 163-182). Rijeka: Faculty of Humanities and Social Research.

Öz, H., Demirezen, M., \& Pourfeiz, J. (2015). Willingness to communicate of EFL learners in Turkish context. Learning and Individual Differences, 37, 269-275. https://doi.org/10.1016/j.lindif.2014.12.009

Pallant, J. (2010). SPSS survival manual: A step by step guide to data analysis using SPSS. Maidenhead: Open University Press/McGraw-Hill. 
Pavičić Takač, V., \& Požega, D. (2011). Personality traits, willingness to communicate and oral proficiency in English as a foreign language. In L. Pon, V. Karabaliş, \& S. Cimer (Eds.), Applied linguistics today: Research and perspectives (pp. 67-82). Berlin, Germany: Lang.

Peng, J. E. (2015). L2 Motivational Self System, Attitudes, and Affect as Predictors of L2 WTC: An Imagined Community Perspective. The Asia-Pacific Education Researcher, 24(2), 433-443. https://doi.org/10.1007/s40299-014-0195-0

Phillips, G. M. (1968). Reticence: Pathology of the normal speaker. Communications Monographs, 35(1), 39-49. https://doi.org/10.1080/03637756809375564

Richmond, V. P., \& Roach, K. D. (1992). Power in the classroom: Seminal studies. In V. P. Richmond, \& J. C. McCroskey (Eds.), Power in the classroom: Communication, control, and concern (pp. 47-66). Hillsdale, NJ: Lawrence Erlbaum.

Savignon, S. J. (2005). Communicative language teaching: Strategies and goals. In E. Hinkel (Ed.), Handbook of research in second language teaching and learning (pp. 653-561). Mahwah, NJ: Lawrence Erlbaum Associates.

Seliger, H. W. (1977). Does practice make perfect? A study of interaction patterns and L2 competence. Language Learning, 27(2), 263-278. https://doi.org/10.1111/j.1467-1770.1977.tb00122.x

Skehan, P. (1989). Individual differences in second language learning. London: Edward Arnold.

Swain, M. (1985). Communicative competence: Some roles of comprehensible input and comprehensible output in its development. In S. Gass, \& C. Madden (Eds.), Input and second language acquisition (pp. 235-253). Rowley, MA: Newbury House.

Şener, S. (2014). Willingness to communicate in English as a foreign language among ELT students in Turkey. Unpublished doctoral dissertation. Çanakkale Onsekiz Mart University, Çanakkale, Turkey.

Wang, W., \& Liu, H. G. (2017). An Empirical Study of Senior High School Students' Willingness to Communicate in English in the Chinese Context. The Proceedings of the $3^{\text {rd }}$ Annual International Conference on Modern Education and Social Science (pp. 466-469). China: Nanjing.

Williams, M., Mercer, S., \& Ryan, S. (2015). Exploring psychology in language learning and teaching. Oxford: Oxford University Press.

Wimolmas, R. (2013). A survey study of motivation in English language learning of first year undergraduate students at Sirindhorn International Institute of Technology (SIIT), Thammasat University. Thailand: Language Institute, Thammasat University.

Yashima, T., Zenuk-Nishide, L., \& Shimizu, K. (2004). The influence of attitudes and affect on willingness to communicate and second language communication. Language Learning, 54(1), 119-152. https://doi.org/10.1111/j.1467-9922.2004.00250.x

\section{Copyrights}

Copyright for this article is retained by the author(s), with first publication rights granted to the journal.

This is an open-access article distributed under the terms and conditions of the Creative Commons Attribution license (http://creativecommons.org/licenses/by/4.0/). 